\title{
Sociodemographic and psychological variables, physical activity and quality of life in elderly at Unati Campinas, São Paulo
}

\author{
Variáveis sociodemográficas, psicológicas, atividade física e \\ qualidade de vida em idosos da Unati de Campinas, São Paulo
}

Variables sociodemográficas, psicológicas, de actividad física y de calidad de vida en ancianos de universidad para personas mayores de Campinas, São Paulo

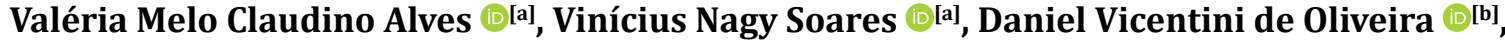 Paula Teixeira Fernandes $\mathbb{B}[\mathrm{a}] *$}

[a] Universidade Estadual de Campinas (Unicamp), Campinas, SP, Brazil

[b] Centro Universitário de Maringá (Unicesumar), Maringá, PR, Brazil

\section{Abstract}

Introduction: Although previous studies have characterized the sociodemographic profile and physical activity level of older people at the Universities of the Third Age (Unati - Universidade Aberta da Terceira Idade), there are research gaps regarding the relationship of these variables with the psychological aspects and the quality of life. Objective: To assess the relationship between sociodemographic and psychological variables, physical activity level and quality of life (QoL) in older people at Unati in Campinas, São Paulo, Brazil.

\footnotetext{
* VMCA: Doctoral student, e-mail: valeriameloclaudino@gmail.com VNS: Doctoral student, e-mail: viniciusnagy@gmail.com DVO: PhD, e-mail: d.vicentini@hotmail.com PTF: PhD, e-mail: paula@fef.unicamp.br
} 
Method: This is a cross-sectional study that recruited 116 older participants of both gender, aged between 60 and 89 years. They were submitted to the following tests: the Rosenberg Self-Esteem Scale (RSES), the Wagnild \& Young's Resilience Scale (RS), the General Self-Efficacy Scale (GSE), the WHOQOL BREF, the Mini-Mental State Examination (MMSE), the Self-Reporting Questionnaire (SRQ20) and the International Physical Activity Questionnaire (IPAQ). The data were analyzed using the Kolmogorov-Smirnov, chi-squared, Fisher's exact, $\mathrm{t}$ - and Mann-Whitney U tests, as well as the generalized linear models. Results: Self-esteem was associated with age, income, schooling level, membership time, and the psychological domain of the WHOQOL-BREF $(\mathrm{p}<0.05)$. Resilience was associated with the schooling level and the psychological domain of the WHOQOLBREF ( $p<0.05$ ), and the self-efficacy with the psychological domain of the WHOQOL-BREF. Common mental disorders were related to the physical and psychological domains of the WHOQOL-BREF, as well as the selfefficacy and being male. The physical activity level showed no correlation with the psychological aspects and the sociodemographic variables studied ( $p>0.05)$. Conclusion: The sociodemographic variables influence emotional aspects, particularly older people's self-esteem and resilience at Unati. Additionally, the psychological domain of the WHOQOL-BREF was a predictor of all the emotional variables in this sample.

Keywords: Aging. Psychology. Self-Esteem. Resilience, Psychological. Quality of Life.

\section{Resumo}

Introdução: apesar de o perfil sociodemográfico e o nível de atividade física de idosos das Universidades da Terceira Idade (Unati) terem sido caracterizados em estudos anteriores, encontram-se lacunas acerca das relações com os aspectos psicológicos e a qualidade de vida. Objetivo: verificar as relações entre variáveis sociodemográficas, psicológicas, nível de atividade física e qualidade de vida em idosos frequentadores da Unati de Campinas, São Paulo. Método: estudo transversal, no qual foram recrutados 116 idosos de ambos os sexos, com idade entre 60 e 89 anos, submetidos à Escala de Autoestima de Rosenberg, Escala de Resiliência de Wagnild \& Young, Escala de autoeficácia geral percebida, WHOQoL Bref, Miniexame do estado mental, Self-report Questionnaire (SRQ20) e o Questionário Internacional de atividade física (IPAQ). Os dados foram analisados pelos testes Kolmogorov-Smirnov, Qui Quadrado, Exato de Fisher, teste t, U de Mann-Whitney e pelos Modelos Lineares Generalizados. Resultados: a autoestima associou-se à idade, renda, escolaridade, ao tempo no programa e ao domínio psicológico do WHOQoL-bref $(p<0,05)$. A resiliência apresentou associação com a escolaridade e ao domínio psicológico do WHOQoL-bref ( $p<0.05)$. A autoeficácia associou-se ao domínio psicológico do WHOQoL-bref. Os transtornos mentais comuns mostraram associação com os domínios físico e psicológico do WHOQoL-bref, à autoeficácia e ao sexo masculino. $O$ nível de atividade física não se associou com os aspectos psicológicos e as variáveis sociodemográficas estudadas $(p>0,05)$. Conclusão: as variáveis sociodemográficas influenciam aspectos emocionais, sobretudo autoestima e resiliência de idosos da Unati. Além disso, o domínio psicológico do WHOQoL-breffoi preditor de todas as variáveis emocionais nesta amostra.

Palavras-chave: Envelhecimento. Psicologia. Autoestima. Resiliência Psicológica. Qualidade de Vida.

\section{Resumen}

Introducción: aunque el perfil sociodemográfico y el nivel de actividad física de los ancianos de las Universidades de Tercera Edad (Unati) se han caracterizado en estudios anteriores, existen lagunas sobre las relaciones con los aspectos psicológicos y la calidad de vida. Objetivo: verificar las relaciones entre las variables sociodemográficas y psicológicas, el nivel de actividad física y la calidad de vida en ancianos que asisten a Unati Campinas, São Paulo. Método: estudio transversal en el que 116 hombres y mujeres de edad avanzada de 60 a 89 años fueron reclutados y sometidos a la Escala de autoestima de Rosenberg, la Escala de resistencia de Wagnild \& Young, la Escala de autoeficacia general percibida, WHOQoL Bref, Miniexame. Cuestionario de autoinforme (SRQ20) y el Cuestionario internacional de actividad física (IPAQ). Los datos fueron analizados por Kolmogorov-Smirnov, Chi-cuadrado, prueba exacta de Fisher, prueba t de Mann-Whitney y modelos lineales generalizados. Resultados: la autoestima 
se asoció con la edad, los ingresos, la educación, el tiempo en el programa y el dominio psicológico de WHOQoL-bref ( $p<0.05)$. La resiliencia se asoció con la educación y con el dominio psicológico de WHOQoL-bref $(p<0.05)$. La autoeficacia se asoció con el dominio psicológico de WHOQoL-bref. Los trastornos mentales comunes se asociaron con los dominios físicos y psicológicos de WHOQoL-bref, la autoeficacia y el género masculino. El nivel de actividad física no se asoció con los aspectos psicológicos y las variables sociodemográficas estudiadas ( $p>0.05$ ). Conclusión: las variables sociodemográficas influyen en los aspectos emocionales, especialmente la autoestima y la capacidad de recuperación de ancianos en Unati. Además, el dominio psicológico WHOQoL-breffue un predictor de todas las variables emocionales en esta muestra.

Palabras clave: Envejecimiento. Psicología. Autoestima. Resiliencia Psicológica. Calidad de Vida.

\section{Introduction}

Staying active is essential to mitigate the physical and emotional decline that occurs with aging by increasing the likelihood of preserving independence and autonomy in old age. The concept of an "active life" does not only encompass the physical domain, since socioenvironmental interactions and emotional balance are decisive factors in life satisfaction [1]. As a result, the recent decades have seen the creation of special programs for older people at higher education institutions, known as Universities of the Third Age (Unati in Brazil). These programs promote active aging through a range of stimulating activities and provide a valuable arena for physical, mental and social development.

Several studies [2-6] have demonstrated that older individuals who remain active, when compared to their nonactive counterparts, tend to have positive emotional skills, with less prevalence of common mental disorders [2], better quality of life [3], resilience [4] and self-esteem [5], in addition to better self-efficacy [6]. It is important to highlight that these studies were conducted with community-dwelling older people's heterogeneous groups, characterized by marked differences in physical and socioeconomic aspects. This heterogeneity is not echoed in the Unatis, whose unique context cannot be extrapolated to the national scenario. Regarding this observation, Roque et al. [7] reported that Unati members are mostly women, with higher schooling levels $(78.7 \%>9$ years of study) and more economically active than the average Brazilian older population.

Although previous studies $[7,8]$ have characterized the sociodemographic profile and the physical activity level of older people at Universities of the Third Age
(Unati), there are research gaps regarding their relationship with psychological aspects. The authors found that more involvement in the Unati for more than one year is associated with lower depressive symptom scores $[8,9]$ and better perceived quality of life in the physical, psychological and social domains [8]. They also observed a significant prevalence in the physical activity $(>75 \%)[8,9]$, but did not investigate its correlation with the psychological aspects. This study believes that identifying the determinants of psychological aspects is essential to provide a new insight on healthy aging, particularly in specific populations. As such, this study aimed to assess the relationship between sociodemographic and psychological variables, physical activity level and quality of life (QoL) in older people at Unati in Campinas, São Paulo, Brazil.

\section{Methods}

Participants

This is a cross-sectional study with 116 older participants of both sexes from the UniversIDADE Program, a Unati affiliated with the State University of Campinas (UNICAMP). The inclusion criteria were a minimum age of 60 years, proven membership in the UniversIDADE Program and no cognitive impairment. The cognitive screening was performed using the Mini-Mental State Examination (MMSE), considering the following cutoff points: illiterate $=20 ; \leq 4$ years of schooling $=25 ;>4$ and $\leq 8$ years of schooling $=26.5$; $>8$ and $\leq 11$ years of schooling $=28 ;>11$ years of schooling $=29$ [10]. The study was approved by the UNICAMP Research Ethics Committee, under protocol number 2.161.868. 
Instruments

Sociodemographic and health status questionnaire: a semi-structured questionnaire in which participants were asked their age, gender, race, schooling level, marital status, income, occupation, membership time, chronic diseases, continued use of medication and reasons for joining the Unati.

The International Physical Activity Questionnaire Short Form (IPAQ-SF) [11] contains 8 questions on the time spent engaging in physical activity in the last week. Each participant was classified considering participation and intensity, [12] as: Very Active (vigorous physical activity $\geq 5$ days/week and $\geq 30$ minutes per session or vigorous physical activity $\geq 3$ days/week and $\geq 20$ minutes walking per session $\geq 5$ days/week and $\geq 30$ minutes per session.); Active (vigorous physical activity $\geq 3$ days/week and $\geq 20$ minutes per session or moderate physical activity or walking $\geq 5$ days/week and $\geq 30$ minutes per session or any combined activity $\geq 5$ days/week, totaling $\geq 150$ minutes/week); Irregularly Active A (meets at least one of the recommended criteria regarding frequency and duration: 5 days/week or 150 minutes/week); Irregularly Active B (did not meet the frequency and duration recommendations), and Sedentary (did not participate in any physical activity lasting at least 10 minutes during the week).

The WHOQOL-BREF (World Health Organization Quality of Life), a translated and abbreviated version [13] of the WHOQOL-100 was used to assess the quality of life. The questionnaire contains 24 items distributed into four domains (social relationships, psychological, physical health and environment) and 2 questions on the overall QoL. The answers are scored from 1 to 5, generating a total score from 0 to 100 for each domain, with the QoL directly proportional to the score.

The General Self-Efficacy Scale (GSE) [14], validated for Brazil [15], consists of 10 items on a scale of 1 (not at all true) to 4 (exactly true), generating a score from 10 to 40 , with the self-efficacy directly proportional to the final score.

The Rosenberg Self-Esteem Scale (RSES) [16] assesses the self-perception of the following aspects: competence, personal satisfaction, strengths and virtues, weaknesses, pride, self-worth, respect and feelings of failure. It contains 10 questions on a scale of 0 (strongly disagree) to 3 (strongly agree) for a final score of 0 to 30 , with self-esteem directly proportional to the score.
The Resilience Scale (RS) [17] evaluates the psychosocial response to important life events and consists of 25 positive statements rated on a scale from 1 (strongly disagree) to 7 (strongly agree). The final score varies from 25 to 175 and is directly proportional to resilience.

\section{Procedures}

Data were collected from May 2017 to February 2018 in classrooms with groups of up to 15 older adults who had been previously informed of the collection by email at Unicamp's UniversIDADE Program. The volunteers remained to participate in the study after completing their activities at the facility. Six of the seven instruments were applied collectively to the whole group, with the main researcher reading the questions aloud and providing guidance, although each participant responded to their own questionnaire. For the cognitive screening, the MMSE was applied individually by a trained researcher. The data collection procedures were explained at the interview, after which a written informed consent was given. The same conditions were used for all subjects, with an average application time of 60 minutes.

\section{Statistical Analysis}

The descriptive statistics (absolute and relative frequencies, mean and standard deviation) were used to characterize the data. The Kolmogorov-Smirnov test was applied to assess the normality of the continuous variables. The chi-squared or Fisher's exact tests were used to compare the categorical variables, and the t-test for independent samples or the Mann-Whitney test to compare continuous variables. The generalized linear models were applied to identify factors, as independent variables, that were associated with self-esteem, resilience, self-efficacy and common mental disorders, with the sociodemographic aspects, chronic diseases, polypharmacy ( $\geq$ continueduse medications), physical activity classification (IPAQ) and the WHOQOL-BREF domains (social relationships, psychological, physical health and environment). Given the low prevalence of 'sedentary' and 'very active' classifications in the sample, a binary variable was created categorizing the participants as "sedentary or insufficiently active" and "active or very active". Initially, all the variables were manually/input into generalized linear models. Next, the less relevant 
variables $(\mathrm{p}>0.05)$ were removed one by one until reaching the lowest Akaike Information Criterion (AIC). Significance was set at 5\% and all analyses were performed using the Statistical Package for the Social Sciences, version 23.

\section{Results}

Of the 128 older adults interviewed for the study, 116 were included in the final analysis and 12 were excluded due to cognitive impairment, with MMSE values between 18 and 20 . With respect to their reasons for joining the UniversIDADE program, approximately $41 \%$ stated they did so to make friends, $37 \%$ to care for their physical health and $35 \%$ for their emotional health, with a low prevalence of motives such as medical $(5 \%)$ or family recommendation (13\%) and becoming a widow(er) (8\%). Regarding the activities carried out, 38\% reported they participated in physical activities to improve their physical (83\%) and/or mental health (41.4\%).

Table 1 presents the remaining characteristics of the participants, grouped by gender. Statistically significant differences were observed for marital status, schooling level, income, chronic diseases and common mental disorders, suggesting worse sociodemographic conditions and health status for the women.
The variables associated with psychological aspects are presented in the tables below. In this sample, classifying physical activity via the IPAQ did not exhibit explanatory power in any of the models for the related variables to psychological aspects and as such has not been included in tables 2 to 5. Table 2 shows the variables associated with self-esteem, whereby age exhibited a negative correlation, while income, schooling level, membership time, and the psychological domain of the WHOQOL-BREF exhibited a positive correlation.

The variables related to resilience are presented in Table 3. While the schooling level and the psychological domain of the WHOQOL-BREF displayed a positive association, the remaining variables could not predict resilience in the participants.

Table 4 shows the variables related to self-efficacy, whereby only the psychological domain of the WHOQOLBREF was a statistically significant predictor, exhibiting a positive correlation.

The variables related to common mental disorders are shown in Table 5, with the physical and psychological domains of the WHOQOL-BREF, self-efficacy and being male found to be statistically significant and negatively correlated with these disorders.

Table 1 - Characterization of the sociodemographic and emotional variables of older people members of Unati, Campinas, São Paulo

\begin{tabular}{|c|c|c|c|c|c|}
\hline \multirow{2}{*}{ Variable } & \multicolumn{2}{|c|}{ Women $(n=84)$} & \multicolumn{2}{|c|}{ Men $(n=32)$} & \multirow{2}{*}{$\mathrm{p}$ value } \\
\hline & $\mathrm{N}$ & $(\%)$ & $\mathbf{N}$ & $(\%)$ & \\
\hline Age, mean (SD) & 68.6 & (7.9) & 69.8 & (6.8) & 0.232 \\
\hline \multicolumn{6}{|l|}{ Marital status } \\
\hline Lives alone & 50 & $(59.5)$ & 9 & (28.1) & \multirow{2}{*}{0.002} \\
\hline Lives with a partner & 34 & $(40.5)$ & 23 & (71.9) & \\
\hline \multicolumn{6}{|l|}{ Race } \\
\hline White & 71 & (84.5) & 26 & (81.3) & \multirow{2}{*}{0.282} \\
\hline Black & 9 & $(10.7)$ & 2 & (6.3) & \\
\hline \multicolumn{6}{|l|}{ Schooling } \\
\hline Complete elementary education & 18 & $(21.4)$ & 1 & $(3.1)$ & \\
\hline High school diploma & 20 & $(23.8)$ & 13 & $(40.6)$ & 0.029 \\
\hline College degree & 46 & $(54.8)$ & 18 & $(56.3)$ & \\
\hline Retired & 69 & $(84.1)$ & 29 & $(90.6)$ & 0.371 \\
\hline \multicolumn{6}{|l|}{ Salary in minimum monthly wages } \\
\hline 1 to 2 & 21 & $(52.6)$ & 1 & $(3.1)$ & \\
\hline 2 to 3 & 18 & $(22.0)$ & 4 & (12.5) & 0.004 \\
\hline 3 or more & 43 & (52.4) & 27 & (84.4) & \\
\hline
\end{tabular}


(Conclusion)

\begin{tabular}{|c|c|c|c|c|c|}
\hline \multirow{2}{*}{ Variable } & \multicolumn{2}{|c|}{ Women $(n=84)$} & \multicolumn{2}{|c|}{ Men $(n=32)$} & \multirow{2}{*}{ p value } \\
\hline & $\mathbf{N}$ & $(\%)$ & $\mathbf{N}$ & $(\%)$ & \\
\hline \multicolumn{6}{|l|}{ Membership time } \\
\hline Recent membership & 31 & $(36.9)$ & 12 & $(37.5)$ & \multirow{4}{*}{0.841} \\
\hline 1 year & 17 & $(20.2)$ & 8 & $(25.0)$ & \\
\hline 2 year & 22 & $(26.2)$ & 6 & (18.8) & \\
\hline 3 year & 14 & $(16.7)$ & 6 & $(18.8)$ & \\
\hline Polypharmacy ( $\geq 5$ continued-use medications) & 14 & $(16.7)$ & 4 & $(12.5)$ & 0.580 \\
\hline Heart disease & 5 & $(6.0)$ & 3 & $(9.4)$ & 0.516 \\
\hline Hypertension & 40 & $(47.6)$ & 14 & $(43.8)$ & 0.709 \\
\hline Stroke & 3 & $(3.6)$ & 3 & $(9.4)$ & 0.207 \\
\hline Diabetes & 15 & $(17.9)$ & 4 & $(12.5)$ & 0.486 \\
\hline Cancer & 3 & $(3.6)$ & 2 & $(6.3)$ & 0.525 \\
\hline Lung disease & 8 & $(9.5)$ & 1 & $(3.1)$ & 0.250 \\
\hline Arthritis & 28 & $(33.3)$ & 3 & $(9.4)$ & 0.009 \\
\hline Osteoporosis & 22 & $(26.2)$ & 1 & $(3.1)$ & 0.005 \\
\hline Depression & 13 & $(15.5)$ & 4 & $(12.5)$ & 0.685 \\
\hline Number of diseases, mean (SD) & 1.6 & $(1.4)$ & 1,1 & $(1.1)$ & 0.071 \\
\hline \multicolumn{6}{|l|}{ IPAQ classification } \\
\hline Active or very active & 42 & $(50.0)$ & 15 & $(46.9)$ & \multirow{2}{*}{0.763} \\
\hline Irregularly active or sedentary & 42 & $(50.0)$ & 17 & $(53.1)$ & \\
\hline \multicolumn{6}{|l|}{ WHOQLL domains, mean (SD) } \\
\hline Psychological & 70.6 & $(11.7)$ & 72,0 & $(15.2)$ & 0.423 \\
\hline Physical & 72.1 & $(14.0)$ & 75,6 & $(15.6)$ & 0.148 \\
\hline Social & 67.9 & $(15.5)$ & 62,7 & $(18.6)$ & 0.196 \\
\hline Environmental & 71.6 & $(11.5)$ & 74,1 & $(13.9)$ & 0.433 \\
\hline \multicolumn{6}{|l|}{ Psychological aspects, mean (SD) } \\
\hline Self-esteem & 33.4 & $(5.3)$ & 33.9 & $(5.2)$ & 0.678 \\
\hline Resilience & 141.4 & $(20.6)$ & 137.8 & $(19.1)$ & 0.151 \\
\hline Self-efficacy & 33.8 & $(4.2)$ & 33.4 & $(5.7)$ & 0.936 \\
\hline Common mental disorders & 4.6 & $(3.9)$ & 2.4 & $(3.4)$ & 0.001 \\
\hline
\end{tabular}

Note: N: absolute frequency; \%: relative frequency; SD: Standard deviation; IPAQ: International Physical Activity Questionnaire; WHOQOL: World Health Organization Quality of Life. Categorical variables compared via the chi-squared and Fisher's exact test.

Continuous variables compared using the t-test for independent samples and Mann-Whitney test. Statistical significance was set at $5 \%$.

Table 2 - Factors associated with elderly members of the Unati, Campinas, São Paulo

\begin{tabular}{lccc}
\hline Predictor & $\boldsymbol{\beta}$ & $\mathbf{9 5 \%} \mathbf{C l}$ for $\boldsymbol{\beta}$ & $\mathbf{p}$ value \\
\hline Age & 0.997 & $0.995-1.000$ & $\mathbf{0 . 0 3 6}$ \\
Income (minimum monthly wages) & & & \\
$\quad 1$ to 2 & 1 & & \\
2 to 3 & 1.027 & $0.958-1.101$ & 0.445 \\
$\quad 3$ or more & 1.075 & $1.010-1.144$ & $\mathbf{0 . 0 2 2}$ \\
Schooling Level & & & \\
$\quad$ Incomplete Elementary Education & 1 & & \\
$\quad$ Complete Elementary Education & 0.864 & $0.776-0.962$ & $\mathbf{0 . 0 0 8}$ \\
$\quad$ High School & 0.986 & $0.891-1.052$ & 0.446 \\
$\quad$ College & 1.055 & $0.934-1.104$ & 0.720 \\
Membership time & & & \\
\hline
\end{tabular}


(Conclusion)

\begin{tabular}{lccc}
\hline Predictor & $\boldsymbol{\beta}$ & $\mathbf{9 5 \%} \mathbf{C l}$ for $\boldsymbol{\beta}$ & $\mathbf{p}$ value \\
\hline Recent member & 1 & & \\
1 year & 1.028 & $0.961-1.100$ & 0.423 \\
2 years & 1.053 & $0.981-1.130$ & 0.150 \\
3 years & 1.076 & $1.011-1.146$ & $\mathbf{0 . 0 2 1}$ \\
Number of diseases & 0.986 & $0.969-1.003$ & 0.105 \\
Psychological domain (WHOQOL) & 1.007 & $1.006-1.009$ & $<\mathbf{0 . 0 0 1}$ \\
\hline
\end{tabular}

Note: Results refer to the generalized linear model, with self-esteem as a dependent variable and sociodemographic and psychological aspects, chronic diseases, polypharmacy and physical activity level as initial predictors. The final model corresponds to the most explanatory variables, defined by the lowest AIC value (Akaike Information Criterion). Statistical significance was set at $5 \%$.

Table 3 - Factors associated with resilience in older people members of the UniversIDADE program

\begin{tabular}{|c|c|c|c|}
\hline Predictor & $\beta$ & $95 \% \mathrm{Cl}$ for $\beta$ & p value \\
\hline \multicolumn{4}{|l|}{ Gender } \\
\hline Female & & 1 & \\
\hline Male & 0.942 & $0.887-1.001$ & 0.053 \\
\hline \multicolumn{4}{|l|}{ Marital status } \\
\hline Lives alone & & 1 & \\
\hline Lives with a partner & 1.040 & $0.988-1.095$ & 0.132 \\
\hline \multicolumn{4}{|l|}{ Income } \\
\hline 1 to 2 minimum monthly wages & & 1 & \\
\hline 2 to 3 minimum monthly wages & 1.061 & $0.981-1.148$ & 0.141 \\
\hline 3 or more & 1.022 & $0.950-1.100$ & 0.557 \\
\hline \multicolumn{4}{|l|}{ Schooling Level } \\
\hline Incomplete Elementary Education & & 1 & \\
\hline Complete Elementary Education & 0.977 & $0.882-1.127$ & 0.958 \\
\hline High School & 1.063 & $0.965-1.171$ & 0.216 \\
\hline College & 1.126 & $1.023-1.239$ & 0.015 \\
\hline \multicolumn{4}{|l|}{ Polypharmacy } \\
\hline No & & 1 & \\
\hline Yes & 1.063 & $0.994-1.137$ & 0.073 \\
\hline \multicolumn{4}{|l|}{ Membership time } \\
\hline Recent member & & 1 & \\
\hline 1 year & 0.993 & $0.918-1.073$ & 0.853 \\
\hline 2 years & 0.974 & $0.899-1.055$ & 0.518 \\
\hline 3 years & 0.938 & $0.873-1.009$ & 0.086 \\
\hline Psychological domain (WHOQOL) & 1.006 & $1.004-1.008$ & $<0.001$ \\
\hline
\end{tabular}

Note: Results refer to the generalized linear model, with resilience as a dependent variable and sociodemographic and psychological aspects, chronic diseases, polypharmacy and physical activity level as initial predictors. The final model corresponds to the most explanatory variables, defined by the lowest AIC value (Akaike Information Criterion). Statistical significance was set at $5 \%$.

Table 4 - Factors associated with self-efficacy in older people members of the UniversIDADE program

\begin{tabular}{lccc}
\hline Predictor & $\boldsymbol{\beta}$ & $\mathbf{9 5 \%} \mathbf{C l}$ for $\boldsymbol{\beta}$ & $\mathbf{p}$ value \\
\hline Age & 0.998 & $0.995-1.001$ & 0.170 \\
Income & & & \\
$\quad 1$ to 2 minimum monthly wages & & 1 & \\
2 to 3 minimum monthly wages & 1.048 & $0.977-1.125$ & 0.192 \\
3 or more & 1.009 & $0.947-1.076$ & 0.782 \\
\hline
\end{tabular}

(To be continued) 
(Conclusion)

\begin{tabular}{lccc}
\hline $\begin{array}{l}\text { Schooling Level } \\
\text { Incomplete Elementary Education }\end{array}$ & & 1 \\
$\quad$ Complete Elementary Education & 1.108 & $0.989-1.241$ & 0.077 \\
$\quad$ High School & 1.027 & $0.940-1.121$ & 0.561 \\
$\quad$ College & 1.075 & $0.984-1.175$ & 0.109 \\
Polypharmacy & & 1 & 0.113 \\
No & & $0.988-1.120$ & 0.358 \\
Yes & 1.052 & $0.999-1.003$ & 0.340 \\
Physical domain (WHOQOL) & 1.001 & $0.999-1.002$ & $<0.001$ \\
Social domain (WHOQOL) & 1.001 & $1.002-1.007$ & $\mathbf{0}$ \\
Psychological domain (WHOQOL) & 1.004 & & \\
\hline
\end{tabular}

Note: Results refer to the generalized linear model, with self-efficacy as a dependent variable and sociodemographic and psychological aspects, chronic diseases, polypharmacy and physical activity level as initial predictors. The final model corresponds to the most explanatory variables, defined by the lowest AIC value (Akaike Information Criterion). Statistical significance was set at $5 \%$.

Table 5 - Factors associated with common mental disorders in older people members of the UniversIDADE program

\begin{tabular}{lccc}
\hline Predictor & $\boldsymbol{\beta}$ & $\mathbf{9 5 \%} \mathbf{C l}$ for $\boldsymbol{\beta}$ & $\mathbf{p}$ value \\
\hline Sex & & 1 & \\
Female & 0.480 & $0.304-0.760$ & $\mathbf{0 . 0 0 2}$ \\
Male & & & \\
Income & & 1 & \\
1 to 2 minimum monthly wages & 1.299 & $0.777-2.174$ & 0.319 \\
2 to 3 minimum monthly wages & 0.877 & $0.560-1.374$ & 0.566 \\
3 or more & 0.989 & $0.965-1.013$ & 0.357 \\
Age & 1.124 & $0.988-1.280$ & 0.077 \\
Number of diseases & 0.978 & $0.963-0.993$ & $\mathbf{0 . 0 0 5}$ \\
Physical domain (WHOQOL) & 0.979 & $0.961-0.997$ & $\mathbf{0 . 0 2 5}$ \\
Psychological domain (WHOQOL) & 0.951 & $0.909-0.995$ & $\mathbf{0 . 0 2 8}$ \\
Self-efficacy & & \\
\hline
\end{tabular}

Note: Generalized linear model with common mental disorders as a dependent variable and social aspects, polypharmacy $(5 \geq$ continued-use medications), self-reported diseases, physical activity level (IPAQ), WHOQOL domains, self-esteem, resilience and self-efficacy as initial predictors. The final model corresponds to the lowest AIC value (Akaike Information Criterion). Statistical significance was set at $5 \%$.

\section{Discussion}

This study assessed the relationship between sociodemographic variables, physical activity level and psychological aspects in older people members of the Unati. The most relevant results suggest an association between sociodemographic variables, selfesteem and resilience, demonstrating the influence of the adaptive skills and individual adjustment on understanding the investigated emotional aspects (i.e. self-esteem, resilience, self-efficacy and common mental disorders).

It is important to characterize the study participants before investigating their emotional aspects, particularly for older women. This contextual analysis is important because the sample consisted primarily of women who, compared to men, lived alone, had a lower income and a worse clinical condition due to the greater prevalence of arthritis and osteoporosis, as well as higher scores for common mental disorders. These results reflect historical social roles, whereby women were tasked with being caregivers and often relegated to the home. Isolation is a known risk factor for physical, cognitive and emotional decline [18], making confinement to the home harmful to older people's health. By contrast, aging can also benefit women, especially once they are widows, since it represents a phase of social 
emancipation and female empowerment that frees them from their historical gender-based roles [19], which could explain the greater female involvement in social programs aimed at the third age.

Self-esteem is a multidimensional concept that encompasses feelings of self-worth, self-confidence, competence and self-respect [20], and involves both affective and cognitive spheres, with feelings and thoughts varying from approval to contempt. The oldest adults in this study were more prone to exhibiting low self-esteem, whereas income and schooling level were protective factors. These findings can be explained by the proximity of death [21] and the multifactorial interactions of the aging process, which affect the physical, social and cognitive domains.

Advancing age is accompanied by a decline in muscle mass and strength [22] that gradually reduces the older people's participation in activities that require mobility. Those with low mobility are less able to take advantage of anti-inflammatory and neuroprotective mechanisms $[23,24]$, exacerbating the cognitive decline. Additionally, friends' death and/or family's structural changes often lead to smaller social circles, with negative consequences for the older people's emotional health, who feel increasingly alone. These losses can result in feelings of vulnerability and in difficulty coping with everyday demands, prompting negative emotions, such as low self-esteem. By contrast, older adults with high schooling and income levels have more resources to deal with the difficulties of life, whether in the form of a better cognitive reserve or because of their financial advantage.

In the field of psychology, resilience is defined as a set of social and intrapsychic processes that enable healthy development even in the face of difficult experiences [25], as well as the ability to adjust to life events [26], which seems to be influenced by schooling level, corroborating previous studies $[27,28]$. A high level of education is a protective factor for cognitive decline $[29,30]$ due to the accumulation of cognitive reserves. Stimulating cognitive skills promotes the neuroplasticity and the formation of alternative neural pathways [31], increasing the ability to cope with the neurophysiological damage inherent to the aging process. In other words, the extent of the cognitive reserve is directly related to resilience and plays a vital role in adjusting to the internal and circumstantial demands of the everyday life.
According to Bandura [32], self-efficacy is an individual's perception of their ability to successfully deal with prospective situations. It is a latent skill based on environmental interactions, directly linked to the task or situation at hand. The results obtained in this study suggest that low self-efficacy increases the likelihood of developing common mental disorders, defined as minor psychiatric disturbances with a set of non-psychotic symptoms that do not meet the formal criteria for a anxiety and/or depression diagnosis [33]. Symptoms of common mental illness include fatigue, depression, insomnia, anxiety, somatic concerns and difficulty concentrating [34]. On analyzing the GSE, this study found that the questions are highly subjective and focus on an individual's ability to deal with difficult everyday situations, relatively similar to resilience. The fact that the physical domain of the WHOQOL-BREF was also a predictor of common mental disorders led this research program to infer the importance of physical abilities, since the difficulty to move or to perform activities of daily living, especially due to chronic pain [35], can lead to emotional suffering, which corroborates studies indicating that physical activity reduces the chances of developing mental illness [2,34].

This study was conducted with an underexplored population in Brazil, making further research important in order to understand the psychological and physical effects of older people's participation in the Unati programs. Limitations include the fact that the sample consisted of members of a Unati from a specific Brazilian region. As a result, the extrapolation of the outcome is limited to older adults who took part in higher education programs and not the country as a whole. Nevertheless, it is important to note that their characteristics corroborate those of other studies with the same population, indicating that the results of this study contribute towards understanding this specific group. As such, the findings of this research program should be interpreted with caution, given its crosssectional design and the homogeneity of the sample, whose schooling and physical activity levels are superior to those normally seen in older people. The same applies to the self-reported measurements obtained, which may have been influenced by social desirability.

\section{Conclusion}

In a sample of the Unati members, this study identified sociodemographic, emotional and health-related differences between genders, with 
sociodemographic variables related to emotional aspects and the psychological domain of the WHOQOL-BREF as a predictor of all the emotional variables. In terms of practical applications, this study contextualized the social roles historically attributed to women and identified the Unati as a way of breaking with the convention and promoting physical, social and psychological development. This research program demonstrated that income and schooling play a vital role in emotional skills, particularly in self-esteem and resilience. Finally, the results showed that older adults with good adaptive skills exhibit higher levels of self-esteem, self-efficacy and resilience and fewer mental illnesses.

Considering that the assessed members of the Unati are above the national average in terms of their physical activity level and cognitive ability, the relationships identified do not reflect the general population. As such, although the results obtained cannot be extrapolated to the population as a whole, they do extend to all Unati members and demonstrate the importance of analyzing psychological variables in this population.

\section{References}

1. Soleman H, Abu-Bader SH, Rogers A, Barusch AS. Predictors of life satisfaction in frail elderly. J Gerontol Soc Work. 2003;38(3):3-17.

2. Rocha SV, Almeida MMG, Araújo TM, Virtuoso JS Jr. Atividade física no lazer e transtornos mentais comuns entre idosos residentes em um município do nordeste do Brasil. J Bras Psiquiatr. 2011;60(2):80-5.

3. Ribeiro CG, Ferretti F, Sá CA. Qualidade de vida em função do nível de atividade física em idosos urbanos e rurais. Rev Bras Geriatr Gerontol. 2017;20(3):330-9.

4. Orsano FE, Sales MM, Browne RAV, Melo GF, Maia EMC. A prática de atividade física e sua influência sobre fatores de resiliência psicológica de idosas. Braz J Biomotricity. 2013;7(1):28-36.

5. Teixeira CM, Nunes FMS, Ribeiro FMS, Arbinaga F, Vasconcelos-Raposo J. Atividade física, autoestima e depressão em idosos. Cuad Psicol Deporte. 2016;16(3):55-66.
6. McAuley E, Jerome GJ, Elavsky S, Marquez DX, Ramsey SN. Predicting long-term maintenance of physical activity in older adults. Prev Med. 2003;37(2):110-8.

7. Roque FP, Vinhas BR, Rebêlo FL, Guimarães HA, Araújo LZS, Goulart BNG et al. Perfil socioeconômico-cultural de uma universidade aberta à terceira idade: reflexo da realidade brasileira? Rev Bras Geriatr Gerontol. 2011;14(1):97-108.

8. Irigaray TQ Schneider RH. Impacto na qualidade de vida e no estado depressivo de idosas participantes de uma universidade da terceira idade. Estud Psicol. 2008;25(4):517-25.

9. Irigaray TQ, Schneider RH. Prevalência de depressão em idosas participantes da Universidade para a Terceira Idade. Rev Psiquiatr Rio Gd Sul. 2007;29(1):19-27.

10. Brucki SMD, Nitrini R, Caramelli P, Bertolucci PHF, Okamoto IH. Sugestões para o uso do mini-exame do estado mental no Brasil. Arq Neuro-Psiquiatr. 2003;61(3B):777-81.

11. Matsudo S, Araújo T, Marsudo V, Andrade D, Andrade E, Braggion G. Questionário internacional de atividade física (IPAQ): estudo de validade e reprodutibilidade no Brasil. Rev Bras Ativ Fis Saude. 2001;6(2):5-18.

12. Lee PH, Macfarlane DJ, Lam TH, Stewart SM. Validity of the international physical activity questionnaire short form (IPAQ-SF): a systematic review. Int J Behav Nutr Phys Act. 2011;8:115.

13. Fleck MPA, Louzada S, Xavier M, Chachamovich E, Vieira G, Santos L et al. Aplicação da versão em português do instrumento abreviado de avaliação da qualidade de vida" WHOQOL-bref". Rev Saude Publica. 2000;34(2):178-83.

14. Schwarzer R, Jerusalem M. Generalized self-efficacy scale. In: Weinman J, Wright $\mathrm{K}$, Johnston M, editors. Measures in health psychology: A user's portfolio: causal and control beliefs. Windsor: NFER-Nelson; 1995. p. 23-25.

15. Souza I, Souza MA. Validação da escala de autoeficácia geral percebida. Rev Univ Rural. 2004;26(1-2):12-7. 
16. Avanci JQ, Assis SG, Santos NC, Oliveira RV. Adaptação transcultural de escala de auto-estima para adolescentes. Psicol Reflex Crit. 2007;20(3):397-405.

17. Pesce RP, Assis SG, Avanci JQ, Santos NC, Malaquias JV, Carvalhaes R. Adaptação transcultural, confiabilidade e validade da escala de resiliência. Cad Saude Publica. 2005;21(2):436-48.

18. Nicholson NR. A review of social isolation: an important but underassessed condition in older adults. J Prim Prev. 2012;33(2-3):137-52.

19. Camarano AA. Mulher idosa: suporte familiar ou agente de mudança? Estud Av. 2003;17(49):35-63.

20. Rosenberg M, Schooler C, Schoenbach C. Self-esteem and adolescent problems: Modeling reciprocal effects. Am Sociol Rev. 1989;54(6):1004-18.

21. Bergman YS, Bodner E. Age is not just a number: age awareness, subjective nearness-to-death, self-esteem, and depressive symptoms among older adults. Aging Ment Health. 2019:1-8.

22. Morley JE, Malmstrom TK. Frailty, sarcopenia, and hormones. Endocrinol Metab Clin North Am. 2013;42(2):391-405.

23. Weuve J, Kang JH, Manson JE, Breteler MM, Ware JH, Grodstein F. Physical activity, including walking, and cognitive function in older women. Jama. 2004;292(12):1454-61.

24. El-Sayes J, Harasym D, Turco CV, Locke MB, Nelson AJ. Exercise-induced neuroplasticity: a mechanistic model and prospects for promoting plasticity. Neuroscientist. 2019;25(1):65-85.

25. Pinheiro DPN. A resiliência em discussão. Psicol Estud. 2004;9(1):67-75.

26. Lerner RM, Weiner MB, Arbeit MR, Chase PA, Agans JP, Schmid KL et al. Resilience across the life span. Annu Rev Gerontol Geriatr. 2012;32(1):275-99.

27. Hardy SE, Concato J, Gill TM. Resilience of community-dwelling older persons. J Am Geriatr Soc. 2004;52(2):257-62.
28. Silva EAPC,Silva PPC,Moura PV, Santos ARM,Dabbicco P, Azevedo AMP et al. Resiliência e saúde: uma análise da qualidade de vida em idosos. Conscientiae Saude. 2012;11(1):111-8.

29. Perneczky R, Drzezga A, Diehl-Schmid J, Schmid G, Wohlschläger A, Kars $S$ et al. Schooling mediates brain reserve in Alzheimer's disease: findings of fluoro-deoxy-glucose-positron emission tomography. J Neurol Neurosurg Psychiatry. 2006;77(9):1060-3.

30. Diniz BSO, Volpe FM, Tavares AR. Nível educacional e idade no desempenho no Miniexame do Estado Mental em idosos residentes na comunidade. Rev Psiquiatr Clin. 2007;34(1):13-7.

31. Bialystok E. The bilingual adaptation: How minds accommodate experience. Psychol Bull. 2017;143(3):233-62.

32. Bandura A. Self-efficacy: Toward a unifying theory of behavioral change. Psychol Rev. 1977;84(2):191-215.

33. Goldberg D. The overlap between the common mental disorders: challenges for classification. Int Rev Psychiatry. 2012;24(6):549-55.

34. Borim FSA, Barros MBA, Botega NJ. Common mental disorders among elderly individuals: a populationbased study in Campinas, Sao Paulo State, Brazil. Cad Saude Publica. 2013;29(7):1415-26.

35. Goodin BR, Bulls HW, Herbert MS. A biopsychosocial perspective on the assessment and treatment of chronic pain in older adults. In: Cordts GA, Christo PJ, editors. Effective treatments for pain in the older patient. New York: Springer; 2019. p. 131-52.

Received in 04/24/2019 Recebido em 24/04/2019 Recibido en 24/04/2019

Approved in 07/01/2020 Aprovado em 07/01/2020 Aprobado en 07/01/2020 